\title{
Formulation, Stability Test and in vitro Penetration Test of Emulgel from Tobacco Leaves Extract
}

\author{
Mahdi Jufri' ${ }^{1}$, Rachmadiva ${ }^{1}$, Misri Gozan ${ }^{2,}{ }^{,}$, Eko Agus Suyono ${ }^{3}$ \\ 'Laboratory of Pharmaceutics and Pharmaceutical Technology Development, Faculty of Pharmacy, Universitas Indonesia, Depok 16424, INDONESIA. \\ 2Department of Chemical Enginering Faculty of Engineering, Universitas Indonesia, Depok, West Java, INDONESIA. \\ ${ }^{3}$ Faculty of Biology, Universitas Gadjah Mada, Bulaksumur, Yogyakarta, INDONESIA
}

\begin{abstract}
Background: Tobacco is widely used as the main raw material of cigarette, however it also can be used as a mosquito repellent. Since tobacco contains nicotine, d-limone, indol, and pyridine, that can be used as an alternative of chemical active of mosquito repellent to substitute N,N-Diethyl-metatoluamide (DEET) and Permethrin. But, as a mosquito repellent, the active ingredients should not able to penetrate the human skin. Methods: This study was conducted to characterize the formula and its stability, as well as the determination nicotine permeation profile through the rat skin. The emulgel was formulated in 4 different compositions: 1 formulation without the presence of tobacco extract and the others three were differentiated by the concentration of the extract loaded in formulations. Result: Organoleptic observation of the emulgel was white and brownish-white that getting darker along with the increasing of tobacco extract concentration. The emulgel of tobacco extract was stable at $4^{\circ} \pm 2^{\circ} \mathrm{C}, 28^{\circ} \pm 2^{\circ} \mathrm{C}, 40^{\circ} \pm 2^{\circ} \mathrm{C}$, after cycling test and centrifugation test. Emulgel with the highest concentration of tobacco extract was tested on its permeability profile of nicotine. The total cumulative of nicotine permeated, percentage of nicotine
\end{abstract}

penetrated through the rat skin and flux of nicotine of tobacco extract emulgel were $14180.628 \mu \mathrm{g} / \mathrm{cm}, 157.562 \%$, and $22.986 \mu \mathrm{g} / \mathrm{cm}^{2} \mathrm{~min}$, respectively. Conclusion: It can be concluded that, the four formulas of emulgel were stable and the percentage of penetrated nicotine was still below the toxic level.

Key words: Emulgel, Nicotine, Penetration, Physical stability, Tobacco.

\section{Correspondence}

Misri Gozan, Department of Chemical Enginering Faculty of Enginering, Universitas Indonesia, Depok 16424, INDONESIA.

Phone: +62217863516

Email: mrgozan@gmail.com

DOI: 10.5530/jyp.2018.2s.13

\section{INTRODUCTION}

According to WHO (World Health Organization), from 1968 until 2009, Indonesia is a country in Southeast Asia which has the highest case of Dengue Fever (DHF) with the lethal rate that keeps increasing every year. Dengue fever transmitted by Aedes aegypti. Increasing growth of A. aegypti due to stagnant water or debris that can hold water for these mosquitoes to multiply. Indonesia still has a low level of hygiene so that it can increase the reproduction of dengue vector. ${ }^{1}$ Also, due to the warming of the rising temperatures on the ground resulted in the increased development of eggs, larvae, and pupae from A. aegypti mosquitoes. ${ }^{2}$

To prevent the occurrence of dengue fever, we can use mosquito repellent to keep away mosquito to touch our skin and bite it. Repellent usually found in lotion or spray dosage form. An active ingredient that usually used in Indonesia in N,N-Diethyl-Meta-Toluamide (DEET) dan permethrin. But if DEET and permethrin used alone in dermal can caused the death of neuron cell, cytoskeleton neuron abnormalities in cortex moto cerebral and cerebellum. If these two are combined can cause physiology and behavior abnormalities and memory disfunction. ${ }^{2}$ Therefore, as a substitute for DEET, repellent may be derived from more non-toxic natural ingredients. Natural ingredients that can use as mosquito repellent are citronella oil, soy oil, geranium oil and also tobacco extract.

Tobacco has long been used as a natural pesticide to kill pests on farms, but it also serves as a fungicide. ${ }^{4}$ Tobacco in Indonesia is manufactured into cigarettes, until 2015 cigarettes produced up to 315 pcs. Unfortunately, because the production of tobacco is processed into cigarettes that can kill up to 200 thousand people. ${ }^{5}$ In a study conducted by
Ellen Dawitri in 2014, has been successfully obtained biopesticide from tobacco by pyrolysis method. The biopesticide samples were formulated into lotion with concentration of $0.0 \%-3.0 \%$ with protection ability up to $57.07 \%$. However, during the physical stability test, it was found that the lotion was unstable due to $\mathrm{pH}$ and viscosity changes. ${ }^{6}$

After being analyzed, tobacco extract contained nicotine, d-limonene, indole, and pyridine which proved to have efficacy as a repellent, and then will be formulated in an emulated dosage forms. Emulgel is a combination of emulsions and gels in which make a water-washable product, stable, and convenient to use. ${ }^{7}$ Also, in the presence of gel phase in the emulsifier preparation it will also cause a decrease in surface tension and interfacial along with the increase of water phase viscosity, so that the emulsion formulation becomes more stable. ${ }^{8}$ Emulgel preparations are also preferred by the community because it is easier to apply. ${ }^{9}$

Nicotine is the most common substance found in tobacco leaves. This nicotine is a toxic substance and has a rapid toxicity that causes symptoms of poisoning with various absorption pathways. The great influence of nicotine intoxication is the occurrence of imbalance on the central nervous system on the peripheral arrangement of ganglia and peripheral autonomic nervous system ganglia. ${ }^{10}$ Therefore, in the presence of nicotine in tobacco has the ability of toxic substances and formulated as emulgel dosage forms. A permeation study was conducted by using Franz's diffusion cell method to evaluate the skin penetration of nicotine of the tobacco extract loaded in an emulgel. 
The skin permeation study was not only conducted for determination of the active absorption and penetration profiles through the skin, but it was also to measure the release of drug capability from the emulgel matrix. This study also could determine the penetration power of the active substance. The Franz diffusion cell that was used in this study consist of several components includes the donor compartment to placed samples for testing through the membrane. Membranes that can be used have several types such as, synthetic membranes, and skins from cadavers. ${ }^{11}$ The membrane serves to separate the donor compartment and the receptor compartment which contains a receiving medium such as a phosphate buffer adapted to the method used. In the choice of medium, the active substance must be in steady state. ${ }^{12}$ The liquid that taken from the receptor compartment is replaced as much as the initial volume liquid is taken. This process is done to keep the receptor fluid volume constant and keep the receptor fluid in steady state. To keep the membrane to stay in place, the membrane is kept in an $\mathrm{O}$ ring. The temperature of the cell is maintained by water circulation using a water jacket that surrounding the receptor compartment. After some time, the drug diffuses into the receptor compartment and will be taken into the content of the medium which is then analyzed using appropriate instruments such as HPLC, spectrophotometry, and other chromatography. ${ }^{13}$

\section{MATERIALS AND METHODS}

\section{Materials and Tools}

Raw material that used in these study are tobacco extract produced by Department of Chemical Engineering, University of Indonesia, Carbopol 940 (Lubrizol), Polysorbate 60 (Tween 60) (Croda), Sorbitan Stearate (Span 60 (Croda), Olive Oil mBHT (BRATACO), Propylene glycol (BRATACO), Aqua Dihidrogenfosfat (BRATACO), Potassium (BRATACO), Potassium Permanganate (BRATACO), $\mathrm{NaOH}$ (BRATACO), Aquademineralisata (deionized water) (BRATACO), Methyl Paraben (Clariant), Propyl Paraben (Clariant), TEA (Petronas), Standard nicotine (Sigma Aldrich), Spraque Dawley rats age of 2-3 months old and body weightof 150-200 g provided by Bogor Agricultural Institute.

The equipment used are an analytical balance (O Hauss, Germany), a homogenizer (IKA,Germany), a pH meter (Metler Toledo, Germany), Brookfield viscometer (USA), oven (Memert ,Germany), centrifuge (Shimadzu, Japan), particle size analyzer (Malvern, England), UV-Vis spectrophotometers (Shimadzu, Japan), microscopes (Olympus, Germany), and Franz diffusion cell.

\section{Emulgel Formulation}

In the formation of the emulsion, the oil phase was made by dissolving span 60 and BHT in olive oil, while the aqueous phase was made by dissolving tobacco leaves extracts, tween 60 , methyl paraben and propyl paraben which had previously dissolved in propylene glycol, then the mixed the mixture into deionized water. Each phase was heated till temperature reached $70-75^{\circ} \mathrm{C}$. After each phase heated, the oil phase and the water phase are mixed using a homogenizer at speed of $2000 \mathrm{rpm}$ until the temperature drops to room temperature and the emulsion well formed.

The hydrogel base was made by swelling carbopol 940 in deionized water and then it was follow by neutralization of mixture $\mathrm{pH}$ by addition of TEA. The increased of $\mathrm{pH}$ after the addition of TEA was increased the viscosity of mixture become a gel texture. Further dispersing of carbopol 940 in deionized water and then mixed using a homogenizer at rotor speed of $2500 \mathrm{rpm}$ to form a viscous gel base.

Emulgel was produced by incorporate the emulsions into the hydrogel base gradually while mixing using a homogenizer at rotor speed of $3000 \mathrm{rpm}$ for $30 \mathrm{~min}$ or until the homogenous emulgel mass is formed well. The ratio between emulsion and gel base is 1:1.

\section{Physical Evaluation of Emulgel Dosage Forms}

After preparation of the emulsifier preparation, a physical evaluation of the preparation is performed for 12 weeks. Physical evaluation was conducted includes organoleptic observation, $\mathrm{pH}$ measurement, viscosity measurement, and rheology analysis, while the emulsion droplets size distribution measurements analyzed by using a particle size analyzer. ${ }^{10}$ A side from doing physical evaluation performed physical stability test in which four formula emulgels stored at low temperature $\left(4^{\circ} \pm 2^{\circ} \mathrm{C}\right)$, room temperature $\left(28^{\circ} \pm 2^{\circ} \mathrm{C}\right)$ and high temperature $\left(40^{\circ} \pm 2^{\circ} \mathrm{C}\right)$ and then observed the changes in $\mathrm{pH}$, viscosity, and rheology every two weeks. The cycling test occur by the store it at $4^{\circ} \pm 2^{\circ} \mathrm{C}$ and $40^{\circ} \pm 2^{\circ} \mathrm{C}$ each for $24 \mathrm{~h}$ ( 1 cycle) and performed a total of 6 cycles, and mechanical test (centrifugation) by centrifuging at a speed of $3800 \mathrm{rpm}$. In a radius of $10 \mathrm{~cm}$ for $5 \mathrm{~h}$ is equivalent to a gravity effect of approximately one year. ${ }^{14}$ After the cycling test, the centrifugation was observed before and after the condition.

\section{Assay of Nicotine}

Calibration curve was made by using a 1000ppm standard solution by diluting $5 \mathrm{ml}$ nicotine $10000 \mathrm{ppm}$ standard and then oxidized with $1 \mathrm{~mL}$ potassium permanganate $0.125 \mathrm{M}$ and $2 \mathrm{~mL}$ sodium hydroxide $10 \mathrm{M}$ and then heated at $100^{\circ} \mathrm{C}$ for $7.5 \mathrm{~min}$. After the room temperature, add with $50 \mathrm{~mL}$ demineralized water. From a stock solution of $1000 \mathrm{ppm}$ diluted to $60,80,100,120,160,180 \mathrm{ppm}$ and then measured at $610 \mathrm{~nm}$ wavelength.

Tobacco extract weighed $2.5 \mathrm{mg}$ and diluted with a little bit water. In other containers, $1 \mathrm{~mL}$ of $0.125 \mathrm{M} \mathrm{KMnO}_{4}$ and $2 \mathrm{~mL} 10 \mathrm{M} \mathrm{NaOH}$ were added, and the tobacco extract and $20 \mathrm{~mL}$ of demineralized water were added. The mixture was heated at $100^{\circ} \mathrm{C}$ for $7.5 \mathrm{~min}$. Then it was cooled to room temperature and fed into a $25 \mathrm{~mL}$ tin flask and measured taken at a wavelength of $610 \mathrm{~nm}$.

Preparations were weighed $1 \mathrm{~g}$ emulgel then dissolved into $50 \mathrm{ml}$ of water, from this the solution taken $5 \mathrm{ml}$ and $1 \mathrm{ml} 0.125 \mathrm{M}$ oxidized with potassium permanganate and $2 \mathrm{ml}$ of $10 \mathrm{M}$ sodium hydroxide, then added demineralized water $20 \mathrm{ml}$ and heated at $100^{\circ} \mathrm{C}$ for $7.5 \mathrm{~min}$. Then cool it down to room temperature and put into a $25 \mathrm{ml}$ tin flask and measured taken at $610 \mathrm{~nm}$ wavelength.

\section{Penetration Test of Franz Diffusion Cells}

Rat test that will be used is Spraque Dawley strain female of 2-3 months old age with weight $\pm 150-200 \mathrm{~g}$ drug using ether. The rat skin was obtained by removing the skin of the abdominal mice whose lashes were carefully shaved and the subcutaneous fat layer removed. Treatment in these test animals has passed the ethical review with the protocol number: 17-03-0231. In the receptor compartment, a phosphate buffer medium of $\mathrm{pH} 7.4$ was maintained at $37 \pm 0,5^{\circ} \mathrm{C}$ with $250 \mathrm{rpm}$ stirring speed. Sampling was performed by taking $2 \mathrm{ml}$ of a solution from the receptor compartment after $5,10,15,30,45,60,90,120$, and 180 . The samples were analyzed according to the nicotine assay method described previously. The penetrated nicotine content was determined and calculated. The flux and the cumulative amount of nicotine contained in the receptor fluid was taken at every sampling time. The sample solution was immediately replaced with phosphate buffer $\mathrm{pH} 7.4$ to keep the fluid volume in constant. ${ }^{14,15}$

Calibration curve was made by reacting nicotine with $0.125 \mathrm{M}$ potassium permanganate and $10 \mathrm{M}$ sodium hydroxide. After mixing, $5 \mathrm{mg}$ of the nicotine standard was dissolved in $\pm 20 \mathrm{~mL}$ of phosphate buffer $\mathrm{pH}$ 7.4 , then heated in $100^{\circ} \mathrm{C}$ water bath for $7.5 \mathrm{~min}$. The mixture was introduced into a $50 \mathrm{ml}$ flask and then adjusted the volume with phosphate buffer $\mathrm{pH}$ 7.4. From the solution was obtained a standard solution of 100 ppm nicotine. This standard solution was diluted to $40,35,30,25,20$, 
Table 1: Formulation of Tobacco Leaves Extract Emulgel.

\begin{tabular}{ccccc}
\hline Material & $\mathbf{B}_{\mathbf{0}}(\%)$ & $\mathbf{F 1}(\%)$ & F2(\%) & F3(\%) \\
\hline Tobacco extract & 0 & 0.5 & 1.5 & 3 \\
Carbopol 940 & 2 & 2 & 2 & 2 \\
Zaitun oil & 5 & 5 & 5 & 5 \\
Tween 60 & 1.13 & 1.13 & 1.13 & 1.13 \\
Span 60 & 3.87 & 3.87 & 3.87 & 3.87 \\
Methyl paraben & 0.18 & 0.18 & 0.18 & 0.18 \\
Propyl paraben & 0.02 & 0.02 & 0.02 & 0.02 \\
BHT & 0.01 & 0.01 & 0.01 & 0.01 \\
Propylene glycol & 10 & 10 & 10 & 10 \\
TEA & 3 & 3 & 3 & 3 \\
Aquademineralisata & ad 100 & ad 100 & ad 100 & ad 100 \\
\hline
\end{tabular}

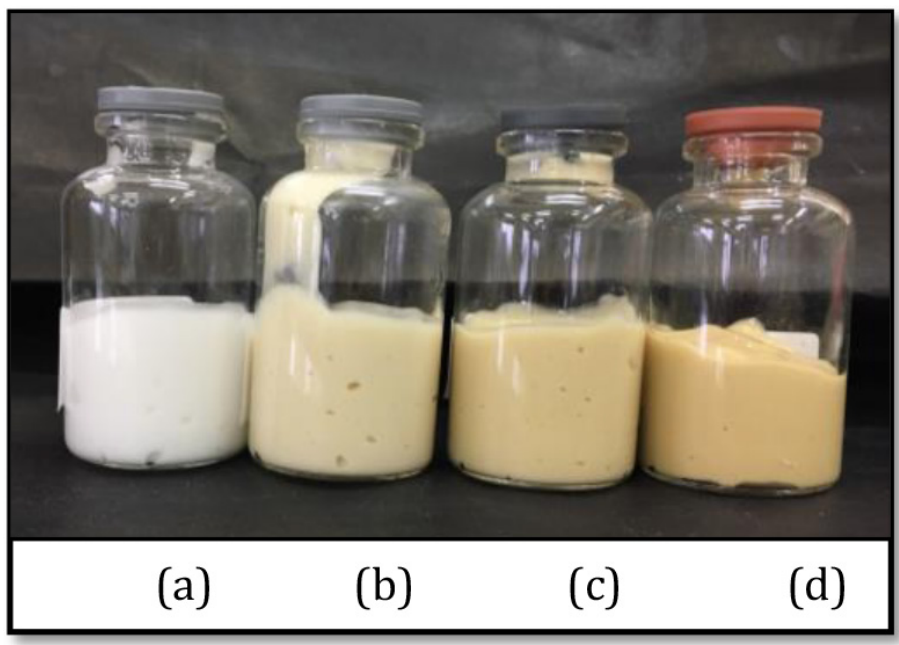

Figure 1: Organoleptic observation of B0 (a), F1 (b), F2 (c), F3(d) emulgel.

15 ppm using phosphate buffer $\mathrm{pH} 7.4$ and measured using spectrophotometry at $610 \mathrm{~nm}$ wavelength. ${ }^{16}$

\section{RESULT}

\section{Evaluation of the Emulgel}

Emulgel has a soft, comfortable and non-oily texture when applied on the skin, smell of honey. The colour of emulgel blank was white and emulgl that contained extract has lightly brown. The result of $\mathrm{pH} \mathrm{B} 0$ measurement was 7.28 , formula 17,1 , formula 26,95 , formula 36,68 . (Figure 1 )

The measurement of viscosity of blank formula at week 0 was $192,000 \mathrm{cps}$, which is containing $0.5 \%$ tobacco extract; $1.5 \%$; $3 \%$ respectively is 192,$000 ; 176,000 ; 168,000 \mathrm{cps}$ at a speed of $0.5 \mathrm{rpm}$ (Figure 2). Measurement of average globular diameter of 4 emulgel with concentrations of $0.5 \%, 1 \%$, $5 \%, 3 \%$ respectively that is $2.65,2.58,2.63 \mu \mathrm{m}$ which is smaller than $2.7 \mu \mathrm{m}$. There is no organoleptic changes and no phase syneresis and separation after physical stability test, cycling tes, and mechanical test. The $\mathrm{pH}$ measurements show every two weeks of dominant increase. (Figure 3)

\section{Assay of Nicotine}

Calibration curve obtained the regression equation $\mathrm{y}=0.0042 \mathrm{x}-0.0321$ with value of $r=0.99902$. Nicotine contained in tobacco extract used in the manufacture of emulgel that is as much as $76.75 \%$. The nicotine content obtained from emulgel dosage form with the theoretical content of Formula 1, 2 and 3, respectively are 108.51\%, 103.55\%, 108.49\%

\section{Penetration Test of Franz Diffusion Cells}

Obtained calibration curve is $\mathrm{y}=0.0224 \mathrm{x}-0.1079$ with the value of $\mathrm{r}$ is 0.9973 . The penetration test was performed using the rat skin of a 2-3 months old Spraque Dawley female. Treatment in these test animals has passed the ethical review with the protocol number: 17-03-0231. After penetration test for $3 \mathrm{~h}$ from $1 \mathrm{~g}$ emulgel F3, the result of nicotine penetration through skin membrane was $14180.628 \mu \mathrm{g} / \mathrm{cm}$; the emulgel flux was $22.698 \mu \mathrm{g} / \mathrm{cm}^{2}$ per min. Nicotine concentration is $157.562 \%$. (Figure 4)

\section{DISCUSSION}

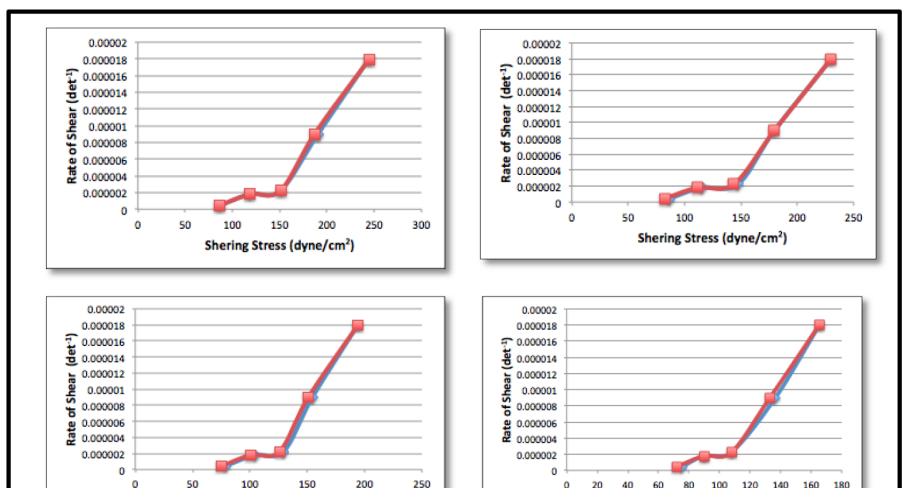

Figure 2: Rheogram emulgel B0 (a), F1 (b), F2 (c), F3(d) week 0.

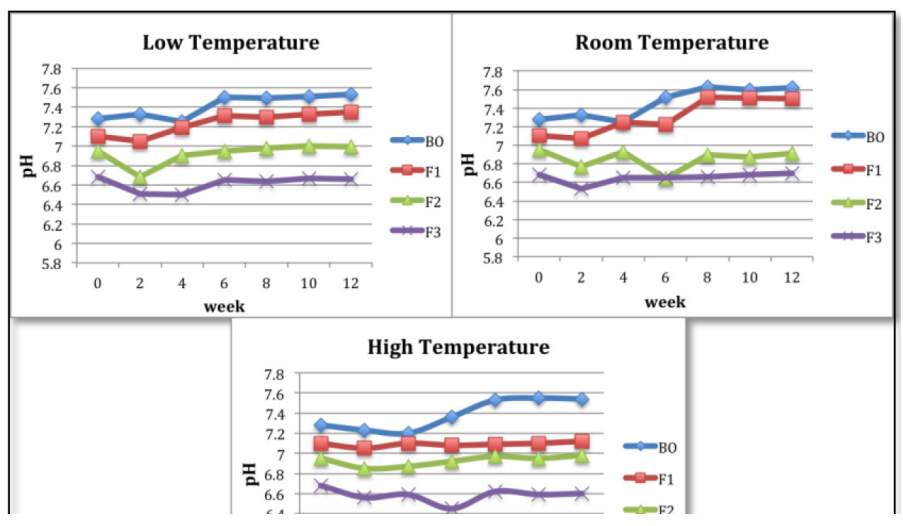

Figure 3: $\mathrm{pH}$ of emulgel after stored in low, room and high temperature.

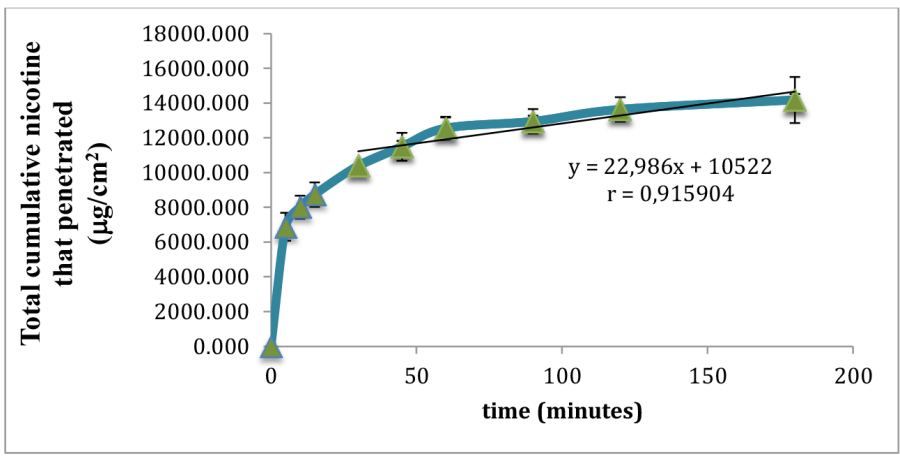

Figure 4: Total cumulative nicotine that penetrated per unit area.

\section{Evaluation of Emulgel}

There is several evaluation that tested on all four formula of emulgel. Organoleptic observation results obtained emulgel brownish white, this is because the extract is blackish brown so along with increasing the amount of tobacco extract used then the emulgel color becomes more 
brownish. The $\mathrm{pH}$ of the dosage decreases as the use of the extract increases due to the extract having a $\mathrm{pH}$ of 4.3 . The $\mathrm{pH}$ values of the four formulas are above the $\mathrm{pH}$ range of the skin but are still tolerable because they are below $\mathrm{pH}$ 8.0-9.0 so they do not kill the microflora. ${ }^{14}$

Viscosity values observed at week 0 and week 12 that kept at room temperature $\left(28^{\circ} \pm 2^{\circ} \mathrm{C}\right)$ are decrease, this is possible because the gel matrix cannot maintain its viscosity. Figure 2 shows that these four emulgel formulas have plastic properties. A plastic properties of emulgel will flow when the force passes its yield's value. The value of the yield value is obtained when extrapolating the straight portion of the curve to the axis of the shear stress and will cut the shear force axis.

On the average globular diameter measurement, it was found that the four emulgel globule size of the formula was still within the range of globular emulsion diameter in general of 0.1-10 $\mu \mathrm{m} .{ }^{14}$ Globule diameter value is taken from $\mathrm{D}_{\mathrm{V} 90}$, which means there is $90 \%$ diameter globule diameter small of the value listed.

In addition to the evaluation, also performed physical stability tests and observed organoleptic changes, $\mathrm{pH}$, and viscosity. The organoleptic of the four emulgel does not change and stable physically. The $\mathrm{pH}$ of the dominant preparation is ascending, but the $\mathrm{pH}$ is still below 8.0-9.0 because in the $\mathrm{pH}$ range the base will remove the $\mathrm{pH}$ of the skin flora. ${ }^{14}$

Furthermore, cycling test and centrifugation test are done. In the cycling test as much as 6 cycles were observed the four emulgel formulas. After test, the result shows that four formulas of emulgel did not change either color, the occurrence of crystallization and syneresis. This indicates that the carbomer other that work as a stabilizer can retain water for not coming out or syneresis. While on the centrifugation test for $5 \mathrm{~h}$ the emulgel preparation remains stable and no phase separation occurs. This indicates that the emulsifier used can retain the emulsion formed.

The assay of Nicotine was performed using UV-Vis spectrophotometry. The tested sample contained nicotine oxidized by using $\mathrm{KMnO}_{4}$ and under alkaline situation by $\mathrm{NaOH}$. After the determination of the level is done the value compared with the theoretical content of nicotine contained in the emulgel. The results obtained to exceed the range of 95-105\%. This is possible because of the use of less precise methods.

In the penetration test using the Franz diffusion cell method, a 2-3-monthold Spraque Dawley strain of white mice weighs 150-200 grams before the abdominal skin membrane removed from the rat. The skin of this mouse was chosen because it has permeability similar to the permeability of the human skin. The percentage of nicotine penetrated that is $157,562 \%$ is as much as $19.71 \mathrm{mg}$. A lethal dose of nicotine between $0.5-1.0 \mathrm{mg} / \mathrm{kg}$ body weight (between 30-60 mg) and toxic effects can occur at a dose of $2 \mathrm{mg}$. ${ }^{15}$ The use of indirect spectrophotometry by means of this oxidation reaction is not appropriate to analyze the penetration test results shown from the amount of nicotine that penetrated is large. This is because the possibility of other ingredients may penetrate can come oxidized like olive oil and provide taken at the same wavelength as nicotine is $610 \mathrm{~nm}$. So the absorption is shown not only represents the penetrated nicotine.

\section{CONCLUSION}

The four formulations of tobacco extracts emulgel prepared and stored at temperature low $\left(4^{\circ} \pm 2^{\circ} \mathrm{C}\right)$, room $\left(28^{\circ} \pm 2^{\circ} \mathrm{C}\right)$, high $\left(40^{\circ} \pm 2^{\circ} \mathrm{C}\right)$ temperatures for 12 weeks were physically stable which was based on the observation on the organoleptic parameters, homogeneity, $\mathrm{pH}$, viscosity, and globule diameter. Formula 3 Emulgel was subjected to a penetration test, based on a 3-hour test using Franz diffusion cells using a SpraqueDawley skin of mice it can be concluded that the nicotine of the emulgel penetrated but did not exceed its toxic limit.

\section{ACKNOWLEDGEMENT}

We gratefully acknowledge the funding from USAID through the SHERA program-Centre for Development of Sustainable Region ( CDSR).

\section{ABBREVIATIONS}

DHF: Dengue Hemorrhagic Fever; DEET: N,N-Diethyl-meta-toluamide BHT: Butyl Hydroxy Toluene; TEA: Triethanolamine.

\section{CONFLICT OF INTEREST}

The authors declare no conflict of interest.

\section{REFERENCES}

1. Ministry of Health Republic Indonesia. Bulettin Window of Epidemiology. Jakarta: Ministry of Health Republic Indonesia. 2010

2. Ramesh V, Vijayakumar S, Manogar P, Mahadevan S, Prabhu S, Murugan R. Mosquito Larvicidal and Pupicidal Activity of Tephrosia purpurea Linn. (Family: Fabaceae) and Bacillus sphaericus against, Dengue Vector, Aedes aegypti. Pharmacog J. 2017;9(6):737-42.

3. Abdel-Rahman A, Shetty A, Abou-Donia M. Subchronic Dermal Application of N,N-Diethyl m-Toluamide (DEET) and Permethrin to Adult Rats, Alone or in Combination, Causes Diffuse Neuronal Cell Death and Cytoskeletal Abnormalities in the Cerebral Cortex and the Hippocampus, and Purkinje Neuron Loss in the Cerebellum. Experimental Neurol. 2001;172(1):153-71.

4. Goldsworthy RP, Fisher NM. Plant Physiology Tropical cultivation, Yogyakarta: Gadjah Mada University Press. 1992:116-8.

5. Ministry of Health Republic Indonesia. Smoking Behaviour in Indonesia Society. Jakarta: Minsitry of Health Republic Indonesia. 2015

6. Jufri M, Irmayanti E, Gozan M. Formulation of Tobacco Based Mosquito Repellent to Avoid Dengue Fever. 2016;9(7):140-5. IJPRIF. ISSN Online: 2455-9563.

7. Mandora P, Dandagi PM, Gadad AP, Ambhore NP. Formulation and Characterization of Tapentadol Loaded Emulgel for Topical Application. Indian J of Pharm Education and Res. 2017;51(4):525-35

8. Gupta A, Mishra A, Singh A, Gupta V, Bansal P. Formulation and Evaluation of Topical Gel of Diclofenak Sodium Using Different Polymers. Drug Invenstion today, 2010;2(5):250-3.

9. Haneefa M, Mohanta GP, Nayar C. Emulgel: An Advanced Review. Journal of Pharmaceutical Sciences and Research. 2013;5(12):254-8.

10. Pomerleau O. Nicotine and the central nervous system: Biobehavioral effects of cigarette smoking. The American J of Med. 1992;93(1):S2-S7.

11. Kumar P, Singh SK, Mishra DN, Girotra P. Enhancement of ketorolac tromethamine permeability through rat skin using penetration enhancers: An ex-vivo study. Int J Pharma Investig. 2015;5(3):142-6.

12. Mannam R, Yallamalli IM. Formulation Optimization and Study on Effect of Penetration Enhancers on Reservoir Transdermal Therapeutic Systems of Hydralazine Hydrochloride. J Young Pharm. 2017;9(4):513-8.

13. Particle Sciences Technical Brief. Development and Validation of in vitro release Testing Methods for Semisolid Formulations. 2009.

14. Ramadon D. Determination of in vitro Penetration test Gel and Emulgel containing Capsaisinoid from Extract of Capsicum frutescens L FMIPA UI, Depok. 2012.

15. Ruela $A L$, et al. In vitro evaluation of transfermal nicotine delivery systems commercially available in Brazil. Brazil: Brazilian J of Pharm Sci. 2013;49(3):579-88.

16. Al-Tamrah SA. Spectrophotometric Determination of Nicotine. Anal Chim Acta. 379.1-2 1999:75-80.

17. Barel AO, Paye M, Maibach HI. (Eds.). Handbook of Cosmetic Science and Technology (Third Edit). New York: Informa Healthcare USA, Inc. 2009:455 